\title{
Extracellular DNA Plays an Important Structural Role in the Biofilm of the Plastic Degrading Actinomycete Rhodococcus ruber
}

\author{
Irit Gilan, Alex Sivan \\ Department of Biotechnology Engineering, Ben-Gurion University of the Negev, Beer-Sheva, Israel \\ Email: sivan@bgu.ac.il
}

Received October 21, 2013; revised November 21, 2013; accepted November 27, 2013

Copyright (C) 2013 Irit Gilan, Alex Sivan. This is an open access article distributed under the Creative Commons Attribution License, which permits unrestricted use, distribution, and reproduction in any medium, provided the original work is properly cited. In accordance of the Creative Commons Attribution License all Copyrights (C) 2013 are reserved for SCIRP and the owner of the intellectual property Irit Gilan, Alex Sivan. All Copyright (C) 2013 are guarded by law and by SCIRP as a guardian.”

\begin{abstract}
Biofilms, the preferred bacterial mode of living and survival, are employed by most microorganisms - which tend to attach to surfaces - to gain physical support, increase nutrient utilization and availability, and augment their resistance against anti-bacterial agents. Rhodococcus ruber (C208) has been shown to form a dense biofilm on polyethylene surfaces while degrading them. Bacterial biofilms comprise bacterial cells embedded in self-secreted extracellular polymeric substances (EPS) whose main components are polysaccharides, proteins and nucleic acids. Revealing the roles of these components will enable further insight into biofilm development and, therefore, the EPS structure-function relationship. The current study focuses on contribution of extracellular DNA to biofilm formation and stability. This was approached by investigating the influence of nucleases on biofilm formation via degradation of their corresponding substrates within the biofilm of C208. RNase application to cultures of C208 decreased biofilm formation. Degradation of biofilm DNA by DNase reduced early-stage biofilm formation by $20 \%-25 \%$ but had no significant effect on established, mature biofilm. Likewise, the addition of DNA to cultures significantly enhanced early-stage biofilm formation by $50 \%-100 \%$. RAPD-PCR analysis revealed different band patterns from intra-cellular DNA and extra-cellular DNA and also between the supernatant and biofilm fractions of extra-cellular DNA, indicating that perhaps only certain DNA molecules are utilized as part of the biofilm.
\end{abstract}

Keywords: Biofilm; Extracellular DNA; DNase; RNase; RAPD-PCR

\section{Introduction}

Polyethylene (PE), the most commonly used synthetic polymer, is highly inert and virtually non-biodegradable. Current global production of PE stands at about 140 million tons per year. In the absence of safe disposal procedures, plastic waste accumulates in the environment posing an ever increasing ecological threat to terrestrial and marine wild life [1].

Biodegradation has been suggested as the best approach for degrading polyethylene (Reviewed by Sivan [1]). The formation of a biofilm on the surface of plastic macro-molecules may accelerate their biodegradation. As a common mode of living adopted by microorganisms is to attached to almost any surface-water interface; biofilms protected communities that allow survival in challenging environments [2-5]. This form of life enables vital interaction between the microorganisms and the surface to which they are attached and markedly increases the survival potential of the microbial community. Biofilms promote utilization of the surface either as support and/or as a substrate.

After initial biofilm establishment, cell-to-cell communication (i.e., quorum sensing) via extracellular signaling molecules regulates further modification and development of the biofilm [6]. In Gram-negative bacteria, the specificity of these signals is mediated by homoserine lactones [7-9], while in Gram-positive bacteria, diverse peptides with limited specificity control of biofilm development [10-12]. Although microbial biofilms often exert various deleterious effects in natural, clinical or industrial environments, they may be beneficial from the biodegradation of complex synthetic polymers, such as 
plastics.

The preferred mode of growth of plastic-degrading bacteria seems to be based on the formation of a biofilm on the plastic surface. Since plastic polymers such as polyethylene and polystyrene are hydrophobic, the bacterial surface must be also hydrophobic to form a stable biofilm [13]. Sakharovskii et al. [14] showed that a correlation exists between carbon starvation and bacterial hydrophobicity. Similarly, Sanin et al. [15] reported changes in bacterial surface hydrophobicity in response to carbon starvation, noting that decreased hydrophobicity was accompanied by reduced bacterial attachment capabilities.

Recently, we isolated a strain of Rhodococcus ruber (designated C208) that utilizes polyethylene as a sole carbon and energy source and that degrades the polymer. This Gram-positive bacterium is an actinomycete that showed a high level of hydrophobicity [16], enabling it to form a dense biofilm on the polyethylene surface. However, little is known about the structure/function relationships in the biofilm. Thus, revealing C208 biofilm composition may provide insight into its mode of action and facilitate its use in biodegradation processes.

Bacterial biofilms are encased within an extracellular matrix consisting of polysaccharides, proteins and nucleic acids [17]. Until recently, polysaccharides were considered as the main component of the biofilm matrix [18-20]. However, recent findings have demonstrated that extracellular proteins and DNA contribute to biofilm stability and regulation. Studies showed that degradation of biofilm proteins by proteases $[21,22]$ and degradation of extracellular DNA (eDNA) by DNase $[23,24]$ reduced the formation and expansion of biofilms. Indeed, eDNA plays a major role in biofilm development, providing structural stability $[24,25]$ and protection against antimicrobial agents $[26,27]$. Recently, eDNA was found to be involved in coordination of bacterial movements during biofilm expansion and mediation of intercellular connectivity within the expanding biofilm of Pseudomonas aeruginosa [28].

Gram-positive bacteria release eDNA to the biofilm, apparently by autolysins (bacterial murein hydrolases). These molecules were reported to be involved in biofilm formation, mediating bacterial lysis in Enterococcus faecalis and Staphylococcus epidermidis [23,27,29,30].

Here we further assess the role of Rhodococcus ruber C208 eDNA in biofilm formation and stability.

\section{Materials and Methods}

\subsection{Bacterial Strains and Culture Conditions}

Cultures of Rhodococcus ruber C208 were cultured in $100 \mathrm{ml}$ nutrient broth (NB; Difco), incubated in flasks $(250 \mathrm{ml})$ on a rotary shaker $(120 \mathrm{rpm})$ at $30^{\circ} \mathrm{C}$ or on nutrient agar (Difco) Petri dishes at $30^{\circ} \mathrm{C}$. Cultures of $\mathrm{Ba}$ - cillus cereus and Pseudomonas aeruginosa from our laboratory collection were maintained in $100 \mathrm{ml}$ Luria Broth (LB) and incubated as above or on LB agar Petri dishes as above.

Experiments were performed in a minimal salts medium (SM; [16]) supplemented with $0.1 \%$ (w/v) mannitol (designated SMM) in polystyrene (PS) microplates (Kartell, Spain) for the biofilm assays. Twenty-four-hour cultures grown in NB medium served as inoculums. Cultures were diluted to reach an $\mathrm{OD}_{595 \mathrm{~nm}}$ of about 0.1 in the SMM medium. Medium without inoculum served as negative control.

\subsection{Enzymatic Treatment of Bacterial Cultures}

Aliquots from diluted cultures were transferred to PS microplates $(190 \mu \mathrm{l}$ per well) and incubated for the desired time at $30^{\circ} \mathrm{C}$. When required, DNase I (RNase-free) or RNase A (DNase and protease-free) (Fermentas, Vilnius, Lithuania) was added to the wells, at time of seeding or after $24 \mathrm{~h}$ of growth, to achieve a final concentration of $15 \mathrm{U} / \mathrm{ml}$ or $50 \mathrm{mg} / \mathrm{ml}$, respectively. DNase I heatinactivated samples $\left(15\right.$-min incubation at $\left.65^{\circ} \mathrm{C}\right)$ served as control. Prior to processing, the turbidity of the culture in the wells was determined at $595 \mathrm{~nm}$ with a plate reader (Biotek ELx808, Winooski, VT, USA) and serial diluted for $\mathrm{CFU}$ counts.

\subsection{Metabolic and Viability Tests of the Bacterial Biofilm}

The metabolic activity of the bacterial biofilm was determined by metabolism monitoring with CTC- Fluorescent Redox Probe (monitoring reduction of CTC (5cyano-2,3-ditolyl tetrazolium chloride) to CTCF (Formazan violet) by bacterial respiration. [31,32].

\subsection{Biofilm Quantification}

Treated and untreated cultures grown in the PS microplates were decanted and the wells were washed twice with distilled water and air-dried. Afterward, $200 \mu \mathrm{l}$ crystal violet $(0.2 \% \mathrm{w} / \mathrm{v})$ (Sigma-Aldrich) were added to the wells, which were incubated for $15 \mathrm{~min}$ and then washed twice with distilled water to remove loosely attached biomass, and the wells were air-dried again. Crystal violet retained by the cells was subsequently re-dissolved in $200 \mu \mathrm{l}$ ethanol $(99 \% \mathrm{w} / \mathrm{v})$, and after incubation of $1 \mathrm{~h}$, absorbance was determined with the plate reader at $595 \mathrm{~nm}$ [33].

\subsection{DNA Extraction and Treatment}

Intra-cellular DNA was extracted from 24-h liquid cultures in SM supplemented with polyethylene films using the UltraClean ${ }^{\mathrm{TM}}$ Microbial DNA isolation kit (MO BIO, Carlsbad, CA, USA) according to the manufacturer's 
instructions. Two fractions of eDNA were extracted: Ssupernatant DNA from cell-free supernatants [by centrifugation at $10,000 \times \mathrm{g}$ for $10 \mathrm{~min}$ at $4^{\circ} \mathrm{C}$ and filtration $(0.2 \mu \mathrm{m})]$ of cultures grown in liquid SM medium supplemented with polyethylene films, and B-biofilm DNA obtained from the washed biofilms adhered to the surface of the polyethylene films. The biofilm was gently scraped, re-suspended in sterile deionized water and vortexed. The suspension was then centrifuged $(10,000 \times \mathrm{g}$ for $2 \mathrm{~min}$ at $4^{\circ} \mathrm{C}$ ) and filtered, as above. This resulted in a cell-free fraction for DNA isolation.

Short fragments of C208 genomic DNA were produced by the amplification of two 16S rRNA gene fragments. The resultant amplicons were confirmed by agarose gel electrophoresis to be about $300 \mathrm{bp}$ and $500 \mathrm{bp}$ (forward primer $8 \mathrm{~F}$, reverse primers $341 \mathrm{R}$ and 518R, respectively). The DNA fragments were added to the growth medium at increasing concentrations, and biofilm formation was compared to that obtained in the presence of intact genomic DNA.

Genomic DNA $(3 \mu \mathrm{g} / \mathrm{ml})$ in Ultrapure $\AA$ water was used to pre-coat the wells of the PS microplate under incubation for $20 \mathrm{~h}$ at $4^{\circ} \mathrm{C}$. The solution was decanted and the wells were air-dried prior to inoculation with the bacteria and assessment of biofilm mass (Modified from [34]). Coating was verified by propidium iodide (Invitrogen, USA) staining according to the manufacturer's instructions.

\subsection{Random Amplified Polymorphic DNA (RAPD)-PCR Analysis}

Profiling of intra- and extra-cellular DNA fractions (obtained as detailed above) was performed by RAPD-PCR using ten mer primers. A primer mixture of 208ACGGCCGACC/228-GCTGGGCCGA was used, Bacillus DNA served as control and gel was run in TAEx1 buffer; Or Primer 241-GCCCGAGCGG was used with Pseudomonas DNA as control and gel run in TBEx1 buffer [35-38].

\section{Results}

\subsection{External DNA and Biofilm DNA}

Extracellular DNA was obtained from two fractions, supernatant DNA (S) and biofilm DNA (B). RAPD-PCR analysis was conducted in an attempt to distinguish between the eDNA sources. The analysis showed different patterns of PCR products between the eDNA fractions and the cellular DNA (C) (Figure 1). This indicates that the eDNA did not originate exclusively from the chromosomal DNA of lysed cells and that possibly it was actively secreted by the bacterium. Moreover, the pattern for eDNA from the biofilm fraction (B) differs from those of the supernatant DNA (S) and cellular DNA (C), which may indicate that only certain DNA molecules are being utilized as part of the matrix EPS (Figure 1).

Extracellular DNA found as part of the bacterial EPS is a novel finding and its presence and characterization in Rhodococcus ruber's biofilm was first investigated in our lab.

\subsection{Effect of Nucleases on the Biofilm}

To further elucidate the role of eDNA in our strain, we amended cultures of C208 with DNase I and RNase A. All biomass quantifications of the biofilm were conducted by crystal violet (CV) staining as detailed in the Materials and Methods chapter. First we verified that the bacteria were not damaged by the nucleases. Respiration test showed no harm to their viability (Figure 2).

The enzymes were added at inoculation time or to 24-h old biofilms. In Figure 3 it can be seen that biofilm development with the addition of nucleases follows the same pattern of the untreated control (Oscillation of attachment-detachment), only its biomass is reduced. The addition of inactivated DNase had no effect on the biofilm indicating that the observed effect is caused by the nucleolytic activity.

Biomass quantification of the biofilm after 5 days showed that both enzymes reduced its formation without affecting culture growth or vitality (Figure 4).

Addition of Bovine Serum Albumin (BSA), caused a significant increase in growth rate, while almost no biofilm was formed (Figure S1). This indicates that the
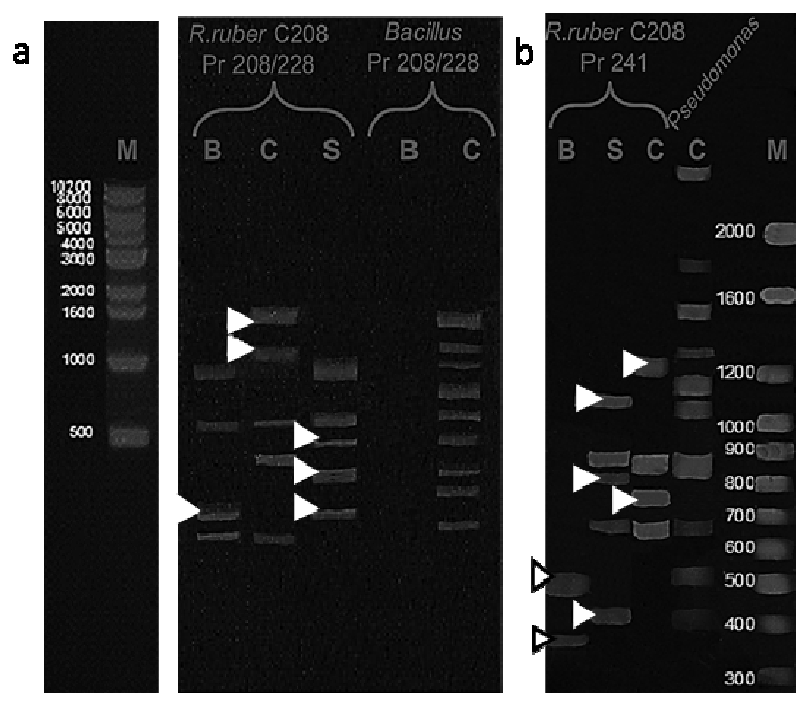

Figure 1. Random Amplified Polymorphic DNA-PCR with 10 mer primers of three fractions of the bacterial culture grown in synthetic medium supplemented with polyethylene. $\mathrm{S}=$ supernatant; $\mathrm{B}=$ biofilm (EPS); $\mathrm{C}=$ cellular; $\mathbf{M}=$ DNA ladder. a) Primer mixture of 208-ACGGCCGAC/228GCTGGGCCGA; Bacillus DNA served as control and gel was run in TAEx1 buffer; b) Primer 241-GCCCGAGCGG; Pseudomonas DNA as control and gel run in TBEx1 buffer. $\triangleright$ Indicates a dissimilar band. 


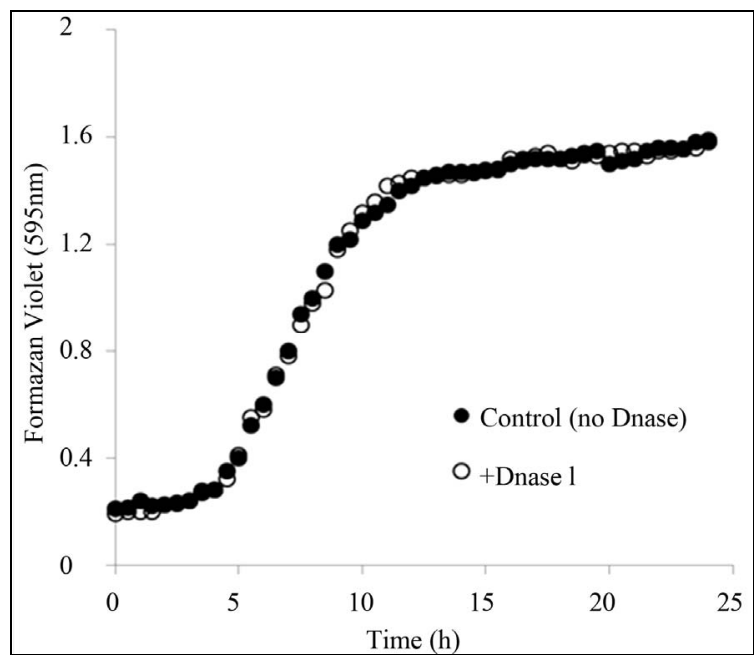

Figure 2. Respiration of Rhodococcus ruber C208 incubated with and without DNase measured by reduction of Tetrazolium to Formazan violet by the cellular electron transport chain.

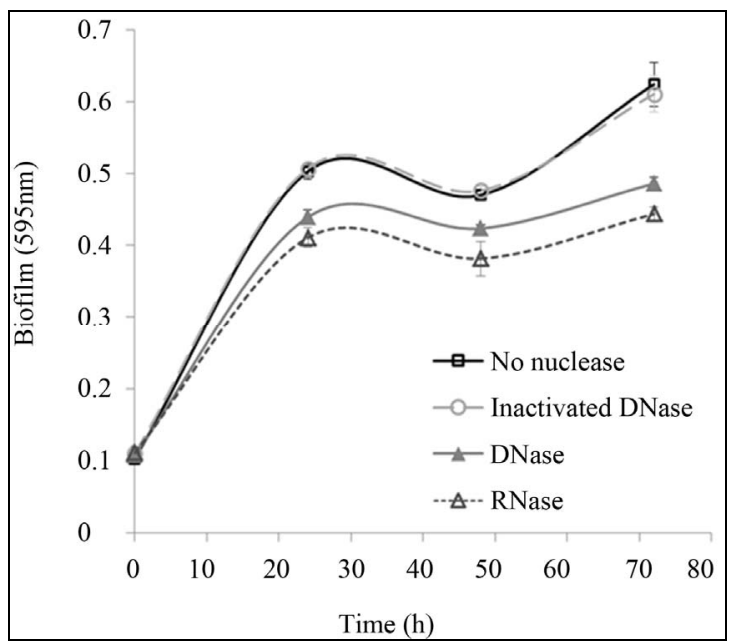

Figure 3. Biofilm formation of $\mathrm{C208}$ during 3 days of growth. Cultures were grown on PS microplates, in SMM supplemented with nucleases $(0.2 \mathrm{mg} / \mathrm{ml})$. Error bars are standard error of the means $(n=6)$.

bacteria preferred the planktonic mode when food was abundant. Addition of DNase I and RNase A to 24-h old biofilms had very little effect (data not shown). These findings suggest that the nucleic acids are important to the formation of $\mathrm{C} 208$ biofilm mainly in the initial stages of its development.

\subsection{Effect of Endogenous and Exogenous DNA on Biofilm}

Since eDNA degradation affected the biofilm we wondered if addition of excess DNA molecules would have any influence on it. DNA was extracted from C208 cells (endogenous DNA) and used at a final concentration of 3 ,
30 or $100 \mathrm{ng} / \mathrm{ml}$. To rule out the effect of self DNA, the same experiments were repeated using salmon sperm DNA (exogenous DNA). As shown in Figure 5, incubation with DNA added at time of seeding enhanced biofilm development by up to $100 \%$. Moreover, this effect was observed with both endogenous (self) and exogenous (foreign) DNA, indicating that this was due to an intrinsic property of the DNA molecule and independent of the exact nucleotide sequence and donor organism.

The addition of DNA to a 2-day-old biofilm enhanced biofilm formation, but cell growth was also improved due to the utilization of the DNA not only as a biofilm support, but also as a nutrient, and the net effect is unequivocal (Figure 6).

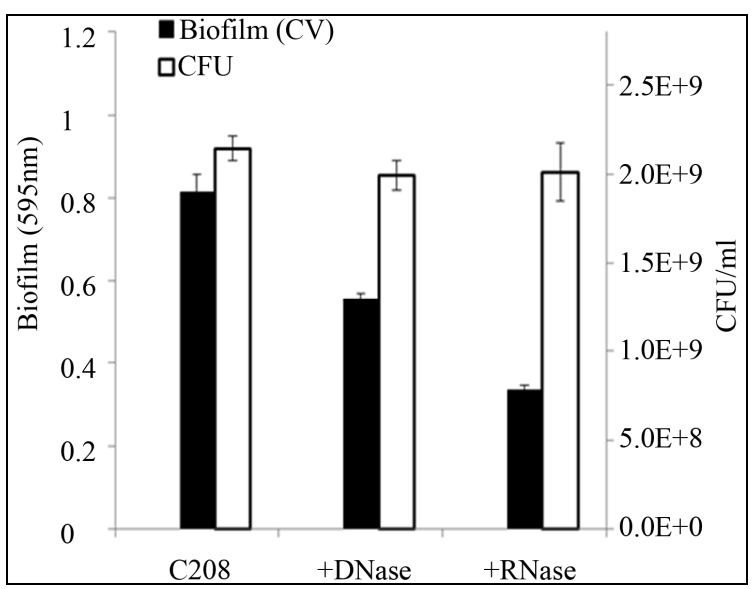

Figure 4. Effect of nucleolytic enzymes on biofilm formation and planktonic growth of $\mathbf{C 2 0 8}$. Biofilm formation ( $\square$ ) and planktonic growth ( $\square$ ) of $\mathrm{C208}$ after 5 days. Cultures were grown on PS microplates, in SMM supplemented with nucleases $(0.2 \mathrm{mg} / \mathrm{ml})$. Error bars are standard error of the means $(n=6)$.

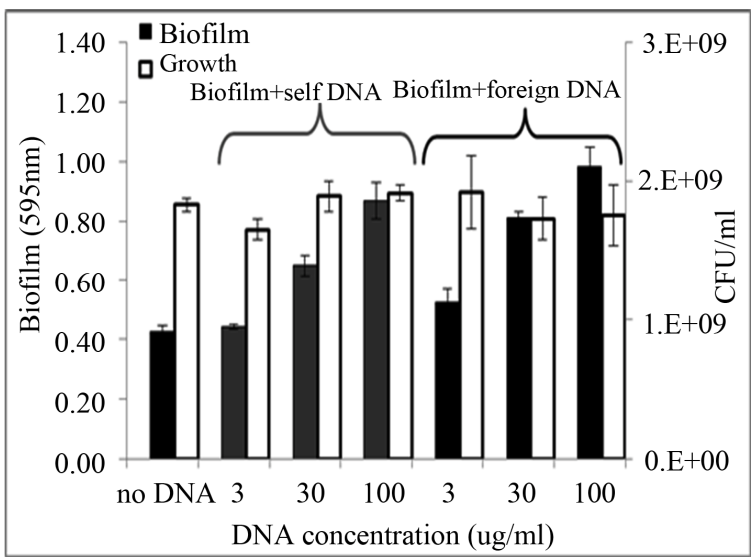

Figure 5. Effect of added DNA on initial biofilm formation and planktonic growth of $\mathbf{C 2 0 8}$. Biofilm formation (a) and planktonic growth ( $\square$ ) of $\mathrm{C208}$ with DNA added to the SMM growth medium at time of seeding. (Foreign DNA-Salmon sperm DNA). Error bars are standard error of the means $(n=3)$. 


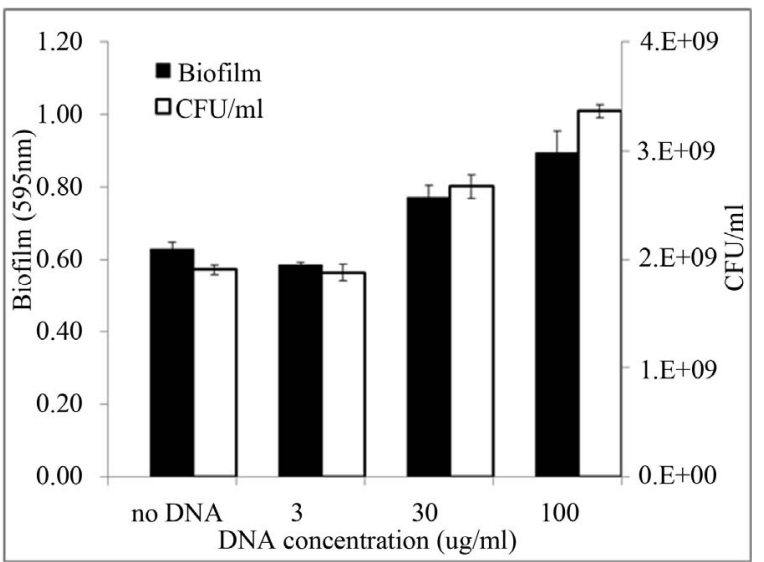

Figure 6. Effect of added DNA on mature biofilm and planktonic growth of $\mathbf{C 2 0 8}$. Biofilm formation and planktonic growth of $\mathrm{C208}$ with DNA added to the SMM growth medium after 2 days of growth. Error bars are standard error of the means $(n=3)$.

To find out whether the size of the DNA molecule is significant for supporting biofilm formation we added short DNA fragments obtained from C208 DNA, as detailed in the Materials and Methods. Our results showed that biofilm development was similar to that of biofilms grown in the absence of additional DNA (Data not shown).

Next, we sought to evaluate whether the DNA-driven enhancement of biofilm formation was apparent only during the initial steps of biofilm establishment (initial cell attachment) or whether the presence of DNA was also required during the subsequent early phases of biofilm development. C208 DNA was used to pre-coat the wells of the PS plates (verified by propidium iodide staining), and the bacteria were incubated in DNA-free medium. The similarity in biofilm masses of the coated well and the uncoated control (Figure 7) Indicates that the observed DNA effect has no bearing on initial cell adherence.

To further understand the contribution of eDNA in biofilm formation, we tried to eliminate the influence of DNase by adding excess DNA to the same growth medium (Figure 8). However, the addition of even large amounts of DNA did not prevent the effect of the DNase, and biofilm formation remained low.

\section{Discussion}

Biofilms are highly structured communities of microorganisms attached to a surface. It has been proposed that all bacterial biofilms have a number of functionally conserved components in common, including the production of an extracellular polysaccharide matrix, extracellular DNA and proteins.

The present study shows that DNA contributes to the development of the biofilm of Rhodococcus ruber C208.

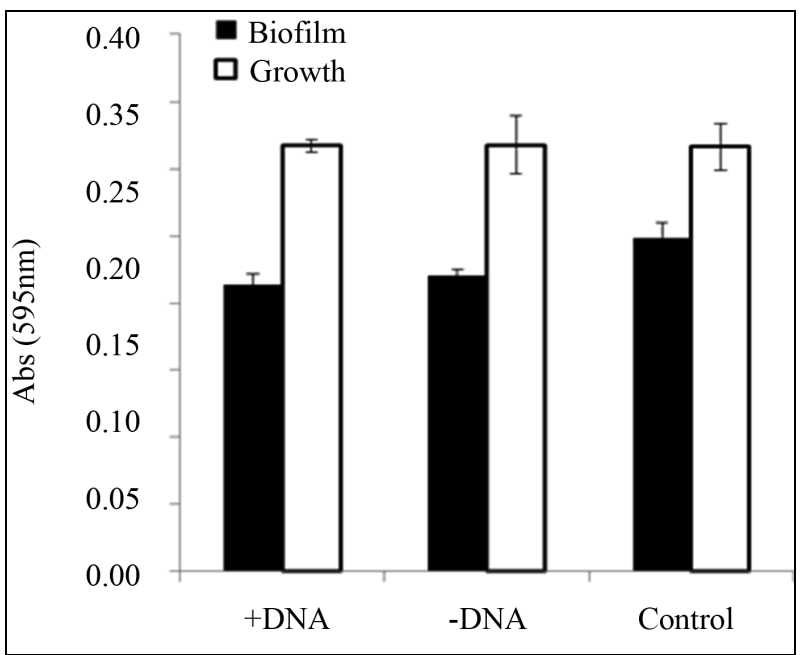

Figure 7. Biofilm formation and planktonic growth of $\mathrm{C208}$ with pre-coating or w/o (control) of genomic DNA. Prior to biofilm inoculation, $3 \mathrm{ng} / \mu \mathrm{l}$ of $\mathrm{C} 208 \mathrm{DNA}$ were incubated in the wells for $20 \mathrm{~h}$ at $4^{\circ} \mathrm{C}$ (modified from [34]). Error bars are standard error of the means $(n=3)$.

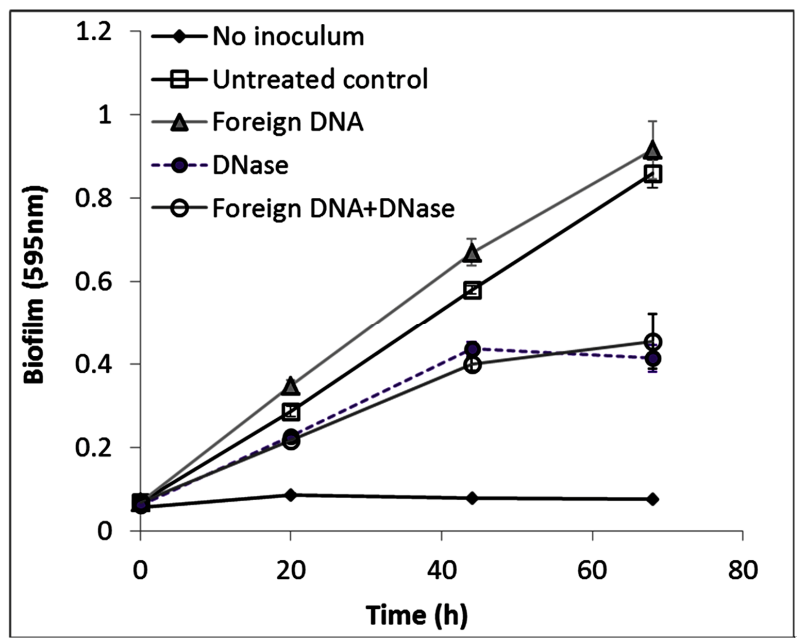

Figure 8. Biofilm formation of $\mathrm{C208}$ during 3 days in SMM supplemented with DNase or DNA or both, compared to untreated control. Foreign DNA = salmon DNA. Error bars are standard error of the means $(n=3)$.

Our findings confirm that extracellular DNA (eDNA) is an important structural component of C208 biofilm. Exposure of the biofilm to DNase I resulted in eDNA degradation and a subsequent reduction in biofilm formation. These results are supported by studies in other species where DNA was reported to be an essential component of the extracellular polymeric substances [24,27,39,40]. Whitchurch et al. [24] and Petersen et al. [41] have described eDNA as one of a major structural components of the Pseudomonas aeruginosa and Streptococcus mutans biofilm matrix, respectively. In $P$. aeruginosa the release of the eDNA macromolecules by the sessile bacteria induced the formation of strengthening linkages between 
the cells within the biofilm [42]. According to Petersen et al. [41], in S. mutans biofilm, the presence of eDNA is associated with the export of a large quantity of competence-signaling peptides (CSP) to the medium.

Mulcahy et al. [26] and Guiton et al. [27] claimed that eDNA plays a major role in biofilm development also by protecting against antimicrobial agents in biofilms of the Gram-negative $P$. aeruginosa and the Gram-positive Enterococcus faecalis, respectively. However, the exact role of these extracellular molecules in the gram-positive and gram-negative biofilm development process is still under intensive research $[28,42]$.

This structural role in C208 biofilm is further reinforced by the effect obtained when the bacteria were supplemented with DNA (either endogenous or foreign), which enhanced biofilm formation. It should be noted that the inhibitory effect of DNase I and enhancing effect of additional DNA occurred mainly during the early stage of biofilm development, while during maturation the effect was less obvious.

Incubation of RNase with cultures of $\mathrm{C} 208$ demonstrated a decrease similar to that obtained with DNase. Existence of extracellular RNA has been reported by Nishimura et al. [43] in the marine bacterium Rhodovulum sulfidophilum. However, the implication that this extracellular RNA is a part of the biofilm is a novel finding. Since significant size differences exist between the DNA and RNA molecules it is reasonable to assume that the similar effect that they exert on the biofilm is not structure-based. One may hypothesize that the mechanisms by which nucleic acids participate in the biofilm differ, such that DNA functions mainly as a structural component whereas RNA may play a more regulatory role, but this should be further explored. Interestingly, Izano et al. [44] showed that in Staphylococcus aureus, eDNA molecule size is important to its function within the biofilm. In agreement with that, the presence of short fragments of DNA (ca. 300 and $500 \mathrm{bp}$ ) in C208 cultures did not enhance biofilm formation and biofilm development was similar to that of biofilms grown in the absence of DNA.

We also found that DNA is not involved in the initial attachment stage since pre-treatment of the plastic substrate with DNA did not enhance biofilm formation. Similar results were obtained with the Gram-positive bacteria Enterococcus faecalis [27] and Streptococcus pneumoniae [34]. On the other hand, in other studies eDNA promoted biofilm attachment $[23,45]$.

Numerous studies indicate that some bacteria produce substantial quantities of extracellular DNA (eDNA) through mechanisms that are thought to be independent of natural cell death. In some cases, eDNA secretion may be mediated by the positive regulation of proteases, which contribute to biofilm formation via the regulation of active cellular autolysis and DNA release [27,29,30]. Other mechanisms, especially in Gram-positive bacteria, involve murein hydrolases, which were reported to be involved in biofilm formation, mediating bacterial lysis in Enterococcus faecalis and Staphylococcus epidermidis $[23,27,29,30,46,47]$. Other reports demonstrate them as adhesins that contribute to bacterial attachment to polymeric surfaces and biofilm formation via the release of eDNA $[23,48,49]$. Elucidation of the role of eDNA in biofilm formation could be advanced by tracking its source. We observed sequence discrepancies between eDNA and cellular DNA in C208 in the RAPD-PCR analysis, a finding that was also confirmed by Nishimura et al. [43], Steinberger \& Holden [50] and Allesen-Holm et al. [37]. These latter studies, however, did not distinguish between the two fractions of eDNA ("supernatant" and "biofilm"). The different band patterns obtained between the supernatant and the biofilm fractions may indicate that only certain DNA molecules are utilized as part of the EPS matrix. For instance, many Rhodococcus strains bear plasmids that may be favorably secreted and serve as eDNA. More evidence is accumulating on the proposed role of those plasmids in gene transfer and recombination [51]. In Rhodococcus sp. strain RHA1, the biphenyl/PCB degradative (bph) genes are distributed around the genome including the linear plasmids [52]. Sequencing of pRHL3 - the $330 \mathrm{~kb}$ linear plasmid of RHA1 - has shown that it is a typical actinomycete invertron, with more than $20 \%$ of its putative genes in catabolic clusters and four regions acquired by recombination. In strain R. erythropolis $\mathrm{BD} 2$ out of 99 putative genes, 23 have catabolic functions and 32 have possible transposition functions. The presence of both the isopropyl benzene degradation (ipb) and bph operons indicates that they were probably acquired via transposition and linear plasmid transfer. Other large linear plasmids of rhodococci encode genes for the catabolism of trichloroethene, naphthalene, toluene, alkylbenzene, biphenyl and chloroaromatic compounds. A plausible explanation for this is that a series of recombinations contributed to the possession of a large number of homologous genes scattered around a large genome comprised of linear plasmids and the chromosome [51]. This series of recombination events could enable the dispersal of newly acquired DNA in bacteria without requiring mobile genetic elements, as suggested by de Vries \& Wackernagel [53] for Acinetobacter.

\section{Conclision}

The findings indicate that eDNA is an important structural component involved in the biofilm formation of C208 to date, but more research is needed to fully elucidate its role. 


\section{REFERENCES}

[1] A. Sivan, "New Perspectives in Plastic Biodegradation," Current Opinion in Biotechnology, Vol. 22, No. 3, 2011, pp. 422-426.

[2] R. Kolter and P. E. Greenberg, "Microbial Sciences: The Superficial Life of Microbes," Nature, Vol. 441, No. 7091, 2006, pp. 300-302. http://dx.doi.org/10.1038/441300a

[3] J. W. Costerton and P. S. Stewart, E. P. Greenberg, "Bacterial Biofilms: A Common Cause of Persistent Infections," Science, Vol. 284, No. 5418, 1999, pp. 1318-1322. http://dx.doi.org/10.1126/science.284.5418.1318

[4] T. C. Mah and G. A. O'Toole, "Mechanisms of Biofilm Resistance to Antimicrobial Agents," Trends in Microbiology, Vol. 9, No. 1, 2001, pp. 34-39.

[5] L. Hall-Stoodley and P. Stoodley, "Evolving Concepts in Biofilm Infections," Cellular Microbiology, Vol. 11, No. 7, 2009, pp. 1034-1043.

http://dx.doi.org/10.1111/j.1462-5822.2009.01323.x

[6] S. Kjelleberg and S. Molin, "Is There a Role for Quorum Sensing Signals in Bacterial Biofilms?" Current Opinion in Microbiology, Vol. 5, No. 3, 2002, pp. 254-258.

[7] M. R. Parsek and E. P. Greenberg, "Acyl-Homoserine Lactone Quorum Sensing in Gram-Negative Bacteria: A Signaling Mechanism Involved in Associations with Higher Organisms," Proceedings of the National Academy of Sciences, Vol. 97, No. 16, 2000, pp. 8789-8793. http://dx.doi.org/10.1073/pnas.97.16.8789

[8] N. A, Whitehead, A. M. L. Barnard, H. Slater, N. J. L. Simpson and G. P. C. Salmond, "Quorum-Sensing in Gram-Negative Bacteria," FEMS Microbiology Reviews, Vol. 25, No. 4, 2001, pp. 365-404. http://dx.doi.org/10.1111/j.1574-6976.2001.tb00583.x

[9] H. Withers, S. Swift and P. Williams, "Quorum Sensing as an Integral Component of Gene Regulatory Networks in Gram-Negative Bacteria," Current Opinion in Microbiology, Vol. 4, No. 2, 2001, pp. 186-193.

[10] B. A. Annous, P. M. Fratamico and J. L. Smith, "Quorum Sensing in Biofilms: Why Bacteria Behave the Way They Do," Journal of Food Science, Vol. 74, No. 1, 2009, pp. R24-R37. http://dx.doi.org/10.1111/j.1750-3841.2008.01022.x

[11] G. M. Dunny and B. A. B. Leonard, "Cell-Cell Communication in Gram-Positive Bacteria," Annual Review of Microbiology, Vol. 51, No. 1, 1997, pp. 527-564. http://dx.doi.org/10.1146/annurev.micro.51.1.527

[12] M. B. Miller and B. L. Bassler, "Quorum Sensing in Bacteria," Annual Review of Microbiology, Vol. 55, No. 1, 2001, pp. 165-199.

http://dx.doi.org/10.1146/annurev.micro.55.1.165

[13] A. Sivan, M. Szanto and V. Pavlov, "Biofilm Development of the Polyethylene-Degrading Bacterium Rhodococcus Ruber," Applied Microbiology and Biotechnology, Vol. 72, No. 2, 2006, pp. 346-352. http://dx.doi.org/10.1007/s00253-005-0259-4

[14] V. V. Sakharovskii, D. I. Nikitin and V. G. Sakharovskii, "Physiological Characterization of the Survival of Some
Gram-Negative Bacteria under Conditions of Carbon Deficiency," Applied Biochemistry and Microbiology, Vol. 35, No. 4, 1999, p. 380.

[15] S. L. Sanin, F. D. Sanin and J. D. Bryers, "Effect of Starvation on the Adhesive Properties of Xenobiotic Degrading Bacteria," Process Biochemistry, Vol. 38, No. 6, 2003, pp. 909-914.

[16] I. G. Orr, Y. Hadar and A. Sivan, "Colonization, Biofilm Formation and Biodegradation of Polyethylene by a Strain of Rhodococcus ruber," Applied Microbiology and Biotechnology, Vol. 65, No. 1, 2004, pp. 97-104.

[17] H. Flemming, T. R. Neu and D. J. Wozniak, "The EPS matrix: The 'House of Biofilm Cells'," Journal of Bacteriology, Vol. 189, No. 22, 2007, pp. 7945-7947. http://dx.doi.org/10.1128/JB.00858-07

[18] S. Molin and T. Tolker-Nielsen, "Gene Transfer Occurs with Enhanced Efficiency in Biofilms and Induces Enhanced Stabilisation of the Biofilm Structure," Current Opinion in Biotechnology, Vol. 14, No. 3, 2003, pp. 255261.

[19] I. W. Sutherland, "The Biofilm Matrix-An Immobilized but Dynamic Microbial Environment," Trends in Microbiology, Vol. 9, No. 5, 2001, pp. 222-227.

[20] R. M. Donlan, "Biofilms: Microbial Life on Surfaces," Emerging Infectious Diseases journal, Vol. 8, No. 9, 2002, pp. 881-890. http://dx.doi.org/10.3201/eid0809.020063

[21] B. R. Boles and A. R. Horswill, "Agr-Mediated Dispersal of Staphylococcus Aureus Biofilms," PLOS Pathogens, Vol. 4, No. 4, 2008, Article ID: E1000052. http://dx.doi.org/10.1371/journal.ppat.1000052

[22] P. Chaignon, I. Sadovskaya, C. Ragunah, N. Ramasubbu, J. Kaplan and S. Jabbouri, "Susceptibility of Staphylococcal Biofilms to Enzymatic Treatments Depends on Their Chemical Composition," Applied Microbiology and Biotechnology, Vol. 75, No. 1, 2007, pp. 125-132. http://dx.doi.org/10.1007/s00253-006-0790-y

[23] Z. Qin, Y. Ou, L. Yang, Y. Zhu, T. Tolker-Nielsen, S. Molin, et al., "Role of Autolysin-Mediated DNA Release in Biofilm Formation of Staphylococcus Epidermidis," Microbiology, Vol. 153, No. 7, 2007, pp. 2083-2092. http://dx.doi.org/10.1099/mic.0.2007/006031-0

[24] C. B. Whitchurch, T. Tolker-Nielsen, P. C. Ragas and J. S. Mattick, "Extracellular DNA Required for Bacterial Biofilm Formation," Science, Vol. 295, No. 5559, 2002, p. 1487.http://dx.doi.org/10.1126/science.295.5559.1487

[25] S. Vilain, J. M. Pretorius, J. Theron and V. S. Brözel, "DNA as an Adhesin: Bacillus Cereus Requires Extracellular DNA to Form Biofilms," Applied and Environmental Microbiology, Vol. 75, No. 9, 2009, pp. 28612868.http://dx.doi.org/10.1128/AEM.01317-08

[26] H. Mulcahy, L. Charron-Mazenod and S. Lewenza, "Extracellular DNA Chelates Cations and Induces Antibiotic Resistance in Pseudomonas Aeruginosa Biofilms," PLoS Pathogens, Vol. 4, No. 11, 2008, Article ID: E1000213. http://dx.doi.org/10.1371/journal.ppat.1000213

[27] P. S. Guiton, C. S. Hung, K. A. Kline, R. Roth, A. L. Kau, E. Hayes, et al., "Contribution of Autolysin and Sortase A 
during Enterococcus Faecalis DNA-Dependent Biofilm Development," Infection and Immunity, Vol. 77, No. 9, 2009, pp. 3626-3638. http://dx.doi.org/10.1128/IAI.00219-09

[28] E. S. Gloag, L. Turnbull, A. Huang, P. Vallotton, H. Wang, L. M. Nolan, et al., "Self-Organization of Bacterial Biofilms Is Facilitated by Extracellular DNA," Proceedings of the National Academy of Sciences, Vol. 110, No. 28, 2013, pp. 11541-11546 http://dx.doi.org/10.1073/pnas. 1218898110

[29] V. C. Thomas, L. R. Thurlow, D. Boyle and L. E. Hancock, "Regulation of Autolysis-Dependent Extracellular DNA Release by Enterococcus Faecalis Extracellular Proteases Influences Biofilm Development," Journal of Bacteriology, Vol. 190, No. 16, 2008, pp. 5690-5698. http://dx.doi.org/10.1128/JB.00314-08

[30] V. C. Thomas, Y. Hiromasa, N. Harms, L. Thurlow, J. Tomich and L. E. Hancock, "A Fratricidal Mechanism Is Responsible for eDNA Release and Contributes to Biofilm Development of Enterococcus Faecalis," Molecular Microbiology, Vol. 72, No. 4, 2009, pp. 1022-12036. http://dx.doi.org/10.1111/j.1365-2958.2009.06703.x

[31] G. G. Rodriguez, D. Phipps, K. Ishiguro and H. F. Ridgway, "Use of a Fluorescent Redox Probe for Direct Visualization of Actively Respiring Bacteria," Applied and Environmental Microbiology, Vol. 58, No. 6, 1992, pp. 1801-1808.

[32] S. Yaqub, J. G. Anderson, S. J. MacGregor and N. J. Rowan, "Use of a Fluorescent Viability Stain to Assess Lethal and Sublethal Injury in Food-Borne Bacteria Exposed to High-Intensity Pulsed Electric Fields," Letters in Applied Microbiology, Vol. 39, No. 6, 2004, pp. 246-251. http://dx.doi.org/10.1111/j.1472-765X.2004.01571.x

[33] G. A. O'Toole and R. Kolter, "Initiation of Biofilm Formation in Pseudomonas Fluorescens WCS365 Proceeds via Multiple, Convergent Signalling Pathways: A Genetic Analysis," Molecular Microbiology, Vol. 28, No. 3, 1998, pp. 449-461. http://dx.doi.org/10.1046/j.1365-2958.1998.00797.x

[34] M. Carrolo, M. João Frias, F. R. Pinto, J. Melo-Cristino and M. Ramirez, "Prophage Spontaneous Activation Promotes DNA Release Enhancing Biofilm Formation in Streptococcus Pneumoniae," PLoS One, Vol. 5, No. 12, 2010, Article ID: E15678.

http://dx.doi.org/10.1371/journal.pone.0015678

[35] E. Mahenthiralingam, M. Campbell, J. Foster, J. Lam and D. Speert, "Random Amplified Polymorphic DNA Typing of Pseudomonas Aeruginosa Isolates Recovered from Patients with Cystic Fibrosis," Journal of Clinical Microbiology, Vol. 34, No. 5, 1996, pp. 1129-1135.

[36] U. Böckelmann, A. Janke, R. Kuhn, T. R. Neu, J. Wecke, J. R. Lawrence and U. Szewzyk, "Bacterial Extracellular DNA Forming a Defined Network-Like Structure," FEMS Microbiology Letters, Vol. 262, No. 1, 2006, pp. 31-38. http://dx.doi.org/10.1111/j.1574-6968.2006.00361.x

[37] M. Allesen-Holm, K. B. Barken, L. Yang, M. Klausen, J. S. Webb, S. Kjelleberg, S. Molin, M, Givskov and T. Tolker-Nielsen, "A Characterization of DNA Release in Pseudomonas Aeruginosa Cultures and Biofilms," Molecu- lar Microbiology, Vol. 59, No. 4, 2006, pp. 1114-1128. http://dx.doi.org/10.1111/j.1365-2958.2005.05008.x

[38] M. Martí, M. P. Trotonda, M. Á. Tormo-Más, M. Vergara-Irigaray, A. L. Cheung, I. Lasa and J. R. Penadés, "Extracellular Proteases Inhibit Protein-Dependent Biofilm Formation in Staphylococcus Aureus," Microbes and Infection, Vol. 12, No. 1, 2010, pp. 55-64.

[39] C. T. Steichen, C. Cho, J. Q. Shao and M. A. Apicella, "The Neisseria gonorrhoeae Biofilm Matrix Contains DNA, and an Endogenous Nuclease Controls Its Incorporation," Infection and Immunity, Vol. 79, No. 4, 2011, pp. 1504-1511. http://dx.doi.org/10.1128/IAI.01162-10

[40] R. Nakao, M. Ramstedt, S. N. Wai and B. E. Uhlin, "Enhanced Biofilm Formation by Escherichia coli LPS Mutants Defective in Hep Biosynthesis," PLoS ONE, Vol. 7, No. 12, 2012, Article ID: e51241. http://dx.doi.org/10.1371/journal.pone.0051241

[41] F. C. Petersen, L. Tao and A. A. Scheie. "DNA BindingUptake System: A Link between Cell-to-Cell Communication and Biofilm Formation," Journal of Bacteriology, Vol. 187, No. 13, 2005, pp. 4392-400. http://dx.doi.org/10.1128/JB.187.13.4392-4400.2005

[42] K. Czaczyk and K. Myszka, "Biosynthesis of Extracellular Polymeric Substances (EPS) and Its Role in Microbial Biofilm Formation," Polish Journal of Environmental Studies, Vol. 16, No. 6, 2007, pp. 799-806.

[43] S. Nishimura, T. Tanaka, K. Fujita, M. Itaya, A. Hiraishi and Y. Kikuchi, "Extracellular DNA and RNA Produced by a Marine Photosynthetic Bacterium Rhodovulum Sulfidophilum," Nucleic Acids Symposium Series, Vol. 3, No. 1, 2003, pp. 279-280. http://dx.doi.org/10.1093/nass/3.1.279

[44] E. A. Izano, M. A. Amarante, W. B. Kher and J. B. Kaplan, "Differential Roles of Poly-N-Acetylglucosamine Surface Polysaccharide and Extracellular DNA in Staphylococcus aureus and Staphylococcus epidermidis Biofilms," Applied and Environmental Microbiology, Vol. 74, No. 2, 2008, pp. 470-476. http://dx.doi.org/10.1128/AEM.02073-07

[45] M. Harmsen, M. Lappann, S. Knøchel and S. Molin, "Role of Extracellular DNA during Biofilm Formation by Listeria monocytogenes," Applied and Environmental Microbiology, Vol. 76, No. 7, 2010, pp. 2271-2279. http://dx.doi.org/10.1128/AEM.02361-09

[46] K. C. Rice, E. E. Mann, J. L. Endres, E. C. Weiss, J. E. Cassat, M. S. Smeltzer and K. W. Bayles, "The Cida Murein Hydrolase Regulator Contributes to DNA Release and Biofilm Development in Staphylococcus aureus," Proceedings of the National Academy of Sciences of the United States of America, Vol. 104, No. 19, 2007, pp. 8113-8118. http://dx.doi.org/10.1073/pnas.0610226104

[47] W. Vollmer and U. Bertsche, "Murein (Peptidoglycan) Structure, Architecture and Biosynthesis in Escherichia coli," Biochimica et Biophysica Acta (BBA)-Biomembranes, Vol. 1778, No. 9, 2008, pp. 1714-1734.

[48] C. Heilmann, M. Hussain, G. Peters and F. Götz, "Evidence for Autolysin-Mediated Primary Attachment of Staphylococcus epidermidis to a Polystyrene Surface," Molecular Microbiology, Vol. 24, No. 5, 1997, pp. 1013-1024. 
http://dx.doi.org/10.1046/j.1365-2958.1997.4101774.x

[49] C. Heilmann, G. Thumm, G. S. Chhatwal, J. Hartleib, A. Uekötter and G. Peters, "Identification and Characterization of a Novel Autolysin (Aae) with Adhesive Properties from Staphylococcus epidermidis," Microbiology, Vol. 149, No. 10, 2003, pp. 2769-2778.

http://dx.doi.org/10.1099/mic.0.26527-0

[50] R. E. Steinberger and P. A. Holden, "Extracellular DNA in Single- and Multiple-Species Unsaturated Biofilms," Applied and Environmental Microbiology, Vol. 71, No. 9, 2005, pp. 5404-5410.

http://dx.doi.org/10.1128/AEM.71.9.5404-5410.2005

[51] M. J. Larkin, L. A. Kulakov and C. C. Allen, "Biodegradation and Rhodococcus-Masters of Catabolic Versatility," Current Opinion in Biotechnology, Vol. 16, No. 3,
2005, pp. 282-290.

http://dx.doi.org/10.1016/j.copbio.2005.04.007

[52] S. Shimizu, H. Kobayashi, E. Masai and M. Fukuda, "Characterization of the 450-kb Linear Plasmid in a Polychlorinated Biphenyl Degrader, Rhodococcus sp. Strain RHA1," Applied and Environmental Microbiology, Vol. 67, No. 5, 2001, pp. 2021-2028. http://dx.doi.org/10.1128/AEM.67.5.2021-2028.2001

[53] J. de Vries and W. Wackernagel, "Integration of Foreign DNA during Natural Transformation of Acinetobacter sp. by Homology-Facilitated Illegitimate Recombination," Proceedings of the National Academy of Sciences of the United States of America, Vol. 99, No. 4, 2002, pp. 20942099. http://dx.doi.org/10.1073/pnas.042263399

\section{Appendix}

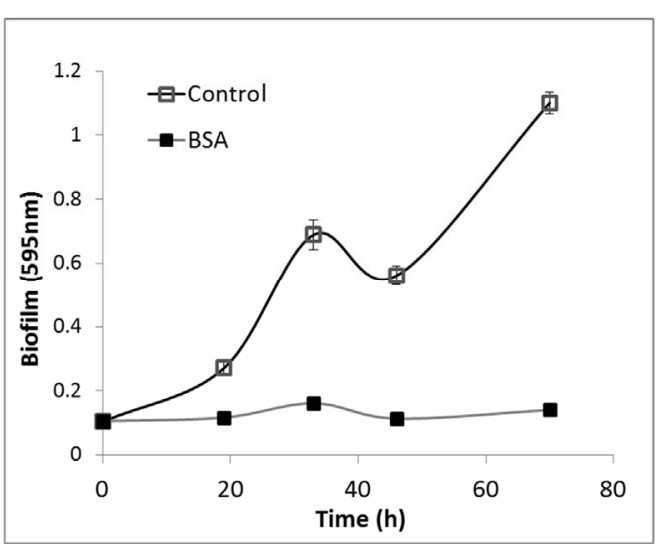

(a)

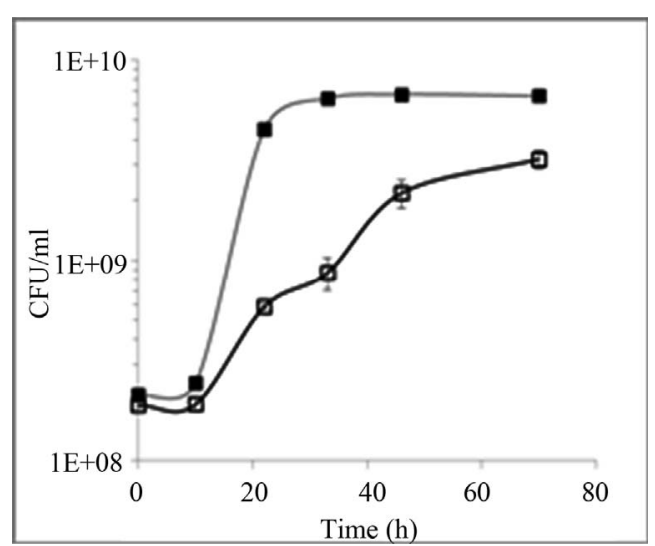

(b)

Figure S1. Effect of non-nucleolytic protein on biofilm formation and planktonic growth of C208. Biofilm formation (a) and planktonic growth (b) of $\mathrm{C208}$ over the course of three days. Cultures were grown on PS microplates in SMM with or without (i.e. control) supplementation of bovine serum albumin (BSA) $(0.2 \mathrm{mg} / \mathrm{ml})$. Error bars are standard error of the means $(\mathrm{n}=$ $6)$. 